\title{
RAPGEF1 Gene
}

National Cancer Institute

\section{Source}

National Cancer Institute. RAPGEF1 Gene. NCI Thesaurus. Code C39938.

This gene plays a role in signal transduction as well as protein binding and trafficking. 